\title{
Association of omentin Val109Asp polymorphism with coronary artery disease
}

\author{
Ümit Yörük, Kürşat Oğuz Yaykaşı*, Hakan Özhan**, Ramazan Memişoğulları***, Ahmet Karabacak**, Serkan Bulur**, \\ Yusuf Aslantaş**, Cengiz Başar**, Ertuğrul Kaya****
}

Department of Medical Biology and Genetics, Institute of Health Science, and *Department of Medical Genetics, **Cardiology, $* * *$ Biochemistry and ****Medical Pharmacology, Faculty of Medicine, Düzce University, Düzce-Turkey

\section{ABSTRACT}

Objective: Coronary artery disease (CAD) is the most important morbidity and mortality disease in the world. It is also one of the leading causes of death in Turkey. Omentin, a recently found adipocytokine, is reported to regulate insulin sensitivity. It has anti-inflammatory properties and is inversely associated with CAD. Omentin gene polymorphism in patients with CAD has not been studied yet. The aim of this study is to investigate the relationship between omentin Val109Asp polymorphism and CAD.

Methods: This is an observational study on genetic association. 157 consecutive patients who had undergone coronary angiography were included in the study. Seventy-five of them had CAD and the rest serves the control group. Val109Asp polymorphism was analyzed and compared. Chi-square test was used in comparison of genotype frequencies, whereas ANOVA and chi-square tests were used in comparison of clinical characteristics according to the genotypes.

Results: There was no significant difference between CAD patients and control subjects regarding omentin Val109Asp polymorphism. However, a 2.5 fold increase in Val/Val (homozygous mutant) genotype was detected in patients with CAD. The OR (80\% CI) for Val/Val genotype was 3.46 (1.14-10.49). Conclusion: Although no significant difference was detected regarding omentin Val109Asp polymorphism, Val/Val genotype frequency was found to be more in patient group than control group. In conclusion, it may be speculated that Val/Val genotype increases the tendency for CAD, but this experiment should done with larger population to clarify this issue. (Anadolu Kardiyol Derg 2014; 14: 511-4)

Key words: Coronary artery disease, omentin, polymorphism, PCR-RFLP

\section{Introduction}

Cardiovascular disease (CVD) is a major cause of mortality worldwide. Even, the relative rate of death decreases, it was estimated that one of every three deaths caused by CVD (1). Coronary artery disease (CAD) usually caused by atherosclerosis involves an ongoing inflammatory response in the coronary arterial vessel wall $(2,3)$. Inflammation is controlled by several hormones and cytokines. Adipose tissue secretes a variety of adipokines, including leptin, adiponectin, visfatin, resistin and omentin, and it is accepted as an endocrine organ because of effecting several organs and systems in metabolism (4-7). Omentin is a recently identified adipokine that is selectively expressed in visceral adipose tissue $(8,9)$. Omentin was identified from a cDNA library from, visceral omental adipose tissue by Yang et al. (10) in 2003. Recent studies have shown that omentin-1 levels are negatively correlated with acute coronary syn- drome, stable angina pectoris (11). Plasma levels of omentin correlated negatively with systolic blood pressure, hemoglobin A1C, body mass index and total cholesterol levels and positively with High Density Lipoprotein (HDL) cholesterol (12). These data indicate that low levels of omentin are associated with CAD and omentin may serve as a novel biomarker for CAD. However; significance of missense polymorphism (Val109Asp) in the human omentin gene in connection with CAD has not been studied. Therefore the aim of this study was to investigate the relationship between omentin Val109Asp polymorphism and CAD.

\section{Methods}

\section{Study design and patients}

This is an observational study on genetic association. 157 consecutive patients who had undergone coronary angiography in Düzce University School of Medicine Cardiology Clinic

Address for Correspondence: Dr. Kürşat Oğuz Yaykaşlı , Düzce Üniversitesi Tıp Fakültesi, Tıbbi Genetik Bölümü, 81620 Konuralp, Düzce-Türkiye

Phone: +90 5337775021 Fax: +90 3805421302 E-mail: kursatyay@yahoo.com

Accepted Date: 17.07.2013 Available Online Date: 19.12.2013

(C) Copyright 2014 by Turkish Society of Cardiology - Available online at www.anakarder.com DOI:10.5152/akd.2013.4932 
between March 2011 and December 2011 were included in the study. Coronary artery disease was defined as $>50 \%$ stenosis in at least one major coronary artery (LMCA, LAD, CX or RCA) in coronary angiography (13). Indications of coronary angiography were positive stress test for ischemia, typical and atypical chest pain in patients with a high risk score for CAD. Exclusion criteria were the presence of malignancy or any acute or chronic inflammatory diseases. The study was approved by the Clinical Research Ethics Committee of Düzce University. An informed consent was obtained from every participant.

\section{Genotyping omentin Val109Asp polymorphism}

Genotyping omentin Val109Asp SNP was determined by PCRbased RFLP (restriction fragment length polymorphism) assay. For this purpose, venous blood was collected from each subject into vacutainer tubes containing EDTA, and genomic DNA was extracted using PureLink ${ }^{\mathrm{TM}}$ Genomic DNA Isolation kit (Invitrogen, Carlsbad, California, USA). A 471 bp DNA fragment was amplified using the upstream primer $5^{\prime}$-GAGCCTTTAGGCCATGTCTCT-3' and the downstream primer 5'-CTCTCCTTCTTCTCCAGCCCAT-3' in Bioneer My GenieTM 96 Gradient Thermal Block (Daejeon, Korea). The PCR cycling conditions were $5 \mathrm{~min}$ at $94^{\circ} \mathrm{C}$ followed by 35 cycles of $1 \mathrm{~min}$ at $94^{\circ} \mathrm{C}, 1 \mathrm{~min}$ at $58^{\circ} \mathrm{C}$, and $1 \mathrm{~min}$ at $72^{\circ} \mathrm{C}$, with a final step at $72^{\circ} \mathrm{C}$ for $10 \mathrm{~min}$. The PCR product subjected to digestion at $37^{\circ} \mathrm{C}$ by Xmil (Accl) restriction enzyme (Fermantas). After digestion, the products were separated by agarose gel, stained with ethidium bromide. As a results of agarose gel electrophoresis, Val/Val (GTC/GTC) homozygotes show two bands (274bp, 197bp), Val/Asp (GTC/GAC) heterozygotes show three bands (471 bp, 274 bp, 197 bp), and Asp/Asp (GTC/GTC) homozygotes show single band (471 bp) (14).

\section{Statistical analysis}

Statistical Package for Social Sciences software (SPSS 12, Chicago, IL, USA) was used for analysis. Descriptive parameters were shown as mean \pm standard deviation or in percentages. Kolmogorov-Smirnov test was used to test normal distribution. Kruskal-Wallis test was used to compare abnormally distributed data among genotype groups. Independent samples t-tests and Pearson's chi-square tests were used to analyze the differences in means and proportions between groups. Abnormally distributed variables were compared using the Mann-Whitney $\mathrm{U}$ test. Odds ratios and their confidence intervals based on genotype frequency were measured by StatCalc of Epilnfo software. Comparisons between groups were tested with ANOVA. Post-hoc analysis was done with Scheffe test. A $p$ value below 0.05 was considered significant.

\section{Results}

\section{Subject characteristics}

Seventy-five patients (48 men and 27 women with a mean age of 64) were diagnosed as having CAD. The rest of the patients (45 men and 37 women with a mean age of 57) had normal vessels or non-significant stenosis served as the control group.
Comparison of demographic and clinical characteristics of the study groups were shown in Table 1.

\section{Association of Omentin Val109Asp polymorphism with coronary artery disease}

According to the omentin gene PCR-RFLP analysis; 5 patients $(6.66 \%)$ had Val/Val genotype, 36 patients $(48 \%)$ had Val/Asp and 34 patients had Asp/Asp genotype in the CAD group whereas 2 participants (2.44\%) had Val/Val genotype, 33 participants (40.24\%) had Val/Asp genotype and 47 participants had (40.24\%) Asp/Asp genotype in the control group, respectively. There was no significant difference in genotype frequency between the groups. Furthermore, odds ratios and their interval confidence intervals based on Asp/Val distribution were measured. The OR for Val/Val homozygous was 3.46, and that of heterozygous was 1.51 . Test for linear trend indicated the $p$ value as 0.082 . The interval estimates of homozygous was $1.14-10.49$ in $80 \%$ confidence interval. The OR's and $80 \% \mathrm{Cl}$ for each genotype were given in Table 2 .

\section{Clinical characteristics according to genotype groups}

The clinical and metabolic characteristics of all study population were further analyzed according to the genotype groups. None of the variables were significantly different except there was a significant female predominance in the Val/Val genotype group (Table 3).

\section{Discussion}

The present study showed that there was no significant difference between CAD patients and control subjects regarding omentin Val109Asp polymorphism. However, a 2.5 fold increase in $\mathrm{Val} / \mathrm{Val}$ (homozygous mutant) genotype was detected in patients with CAD.

The recent researches has been showed that the adipose tissue is not only a repository for lipids but also secretes several hormon like protein called adipokines including leptin, adiponectin, resistin, visfatin and omentin. So, adipose tissue is recognized as an endocrine organ due to the involvement of the adipokines in several vital pyhsiological and pahtological processes. On the other hand, the rate of obesity is increasing rapidly in western world like in our country. Therefore, the researchers have focused on the relationship between $C A D$ and adipose tissue with its products. The adipokines with inflammatory characteristics have become the potential target to be biomarker for CAD (15-17). Up to date, several studies have been conducted, and the association of CAD and leptin (18), resistin (19), adiponectin (20), and visfatin (21) have been reported, but this association remain poorly understood (22).

In this study we investigated that the relationship between $C A D$ and omentin, the last characterized adipokine. Even significantly difference was not found between CAD patients and control subjects regarding omentin Val109Asp polymorphism, $\mathrm{Val} / \mathrm{Val}$ (homozygous mutant) genotype was found 2.5 fold times more in patients with $C A D$ than control group (OR=3.46). 
Table 1. Comparison of clinical and demographic characteristics of the study groups

\begin{tabular}{|c|c|c|c|}
\hline & CAD $(n=75)$ & Control (n=82) & $\boldsymbol{P}$ \\
\hline Age, years & $63.7 \pm 11.6$ & $56.6 \pm 12.1$ & 0.001 \\
\hline $\mathrm{BMI}, \mathrm{kg} / \mathrm{m}^{2}$ & $27.3 \pm 3.8$ & $29.1 \pm 6.4$ & 0.067 \\
\hline Sex, female & 27 & 37 & 0.245 \\
\hline Smokers & 22 & 17 & 0.226 \\
\hline Diabetes mellitus & 25 & 22 & 0.437 \\
\hline Dyslipidemia & 7 & 11 & 0.418 \\
\hline Systolic blood pressure, $\mathrm{mm} \mathrm{Hg}$ & $128 \pm 10$ & $129 \pm 10$ & 0.795 \\
\hline Diastolic blood pressure, $\mathrm{mm} \mathrm{Hg}$ & $81.5 \pm 7.4$ & $81.0 \pm 6.2$ & 0.703 \\
\hline Glucose, mg/dL & $146.8 \pm 81.4$ & $126.6 \pm 58.5$ & 0.122 \\
\hline Creatinine, mg/dL & $0.95 \pm 0.37$ & $0.9 \pm 0.4$ & 0.433 \\
\hline Total cholesterol, mg/dL & $167.5 \pm 48.4$ & $190.2 \pm 41.4$ & 0.010 \\
\hline $\mathrm{HDL}, \mathrm{mg} / \mathrm{dL}$ & $41.8 \pm 11.6$ & $46.4 \pm 12.1$ & 0.044 \\
\hline $\mathrm{LDL}, \mathrm{mg} / \mathrm{dL}$ & $96.6 \pm 36.1$ & $110.4 \pm 35.9$ & 0.049 \\
\hline Triglycerides, mg/dL & $163.1 \pm 93.2$ & $160.5 \pm 72.6$ & 0.087 \\
\hline Omentin, $\mathrm{ng} / \mathrm{mL}$ & $632 \pm 328$ & $565 \pm 395$ & 0.251 \\
\hline
\end{tabular}

Table 2. Comparison of genotypes in CAD patients and control

\begin{tabular}{|c|c|c|c|c|}
\hline Genotype & $\begin{array}{l}\text { CAD } \\
(n=75)\end{array}$ & $\begin{array}{c}\text { Control } \\
(n=82)\end{array}$ & $P$ & $\begin{array}{l}\text { Odds ratios for CAD } \\
\text { risk (80\% Cl) }\end{array}$ \\
\hline Val/Val n (\%) & $5(6.66 \%)$ & $2(2.44 \%)$ & NS & $3.46(1.14-10.49)^{*}$ \\
\hline Val/Asp n (\%) & $36(48 \%)$ & $33(0.24 \%)$ & NS & $\begin{array}{c}1.51(0.99-2.3) \\
1.1(0.51-2.17)^{* *}\end{array}$ \\
\hline Asp/Asp n (\%) & $34(45.33 \%)$ & $47(57.31 \%)$ & NS & $1(1-1)$ \\
\hline \multicolumn{5}{|c|}{$\begin{array}{l}\text { Data are represented as percentages/proportions. *Frequencies are computed using } \\
\text { chi-square test. } \\
\text { *Unadjusted OR. Age and sex adjustment could not be computed due to low number of } \\
\text { subjects. } \\
\text { **Age and sex adjusted OR } \\
\mathrm{Cl} \text { - confidence interval, (Val/Val=GTC/GTC, Val/Asp=GTC/GAC, Asp/Asp=GAC/GAC), } \\
\text { NS - non-significant }\end{array}$} \\
\hline
\end{tabular}

Omentin is expressed in visceral adipose tissue and it has anti-inflammatory effects (23). The omentin gene is located in the 1q22-q23 chromosomal region. It has been linked to type 2 diabetes in several populations $(8,9)$, suggesting that omentin may be a candidate gene for type 2 diabetes susceptibility in humans. The relationship between circulating omentin-1 with cardiovascular health were investigated in several clinical studies. Moreno-Navarrete et al. (24) demonstrated that omentin was independently associated with endothelial dysfunction after controlling for adiposity, age, and inflammation in subjects with impaired glucose tolerance. A negative correlation of omentin was also shown with increased carotid-intima media thickness in patients with metabolic syndrome (25). De Souza et al. (26) showed that omentin gene expression was decreased with obesity and decreased omentin levels were associated
Table 3. Comparison of clinical characteristics according to the genotypes

\begin{tabular}{|l|c|c|c|c|c|}
\hline & $\begin{array}{c}\text { Val/Nal } \\
\text { (n=7) }\end{array}$ & $\begin{array}{c}\text { Val/Asp } \\
\text { (n=69) }\end{array}$ & $\begin{array}{c}\text { Asp/Asp } \\
\text { (n=81) }\end{array}$ & $\mathbf{F}$ & $\boldsymbol{P}$ \\
\hline Age, years & $64 \pm 5.73$ & $61 \pm 2.14$ & $59 \pm 2.14$ & 0.517 & 0.597 \\
\hline BMI, kg/m² & $28.4 \pm 2.79$ & $27.1 \pm 0.97$ & $29.5 \pm 0.97$ & 3.095 & 0.050 \\
\hline Sex; female & 6 & 25 & 33 & & 0.040 \\
\hline Smokers & 1 & 19 & 19 & & 0.836 \\
\hline Dyslipidemia & 0 & 10 & 8 & & 0.676 \\
\hline Diabetes mellitus & 2 & 16 & 29 & & 0.180 \\
\hline CAD & 5 & 36 & 34 & & 0.202 \\
\hline $\begin{array}{l}\text { Systolic blood } \\
\text { pressure, mm Hg }\end{array}$ & $132 \pm 59.40$ & $150 \pm 20.54$ & $129 \pm 20.54$ & 0.524 & 0.593 \\
\hline $\begin{array}{l}\text { Diastolic blood } \\
\text { pressure, mm Hg }\end{array}$ & $85 \pm 3.48$ & $81 \pm 1.20$ & $82 \pm 1.20$ & 0.942 & 0.392 \\
\hline Glucose, mg/dL & $132 \pm 33.30$ & $133 \pm 13.44$ & $140 \pm 13.44$ & 0.139 & 0.871 \\
\hline Creatinine, mg/dL & $0.75 \pm 0.19$ & $0.97 \pm 0.08$ & $0.9 \pm 0.08$ & 0.872 & 0.067 \\
\hline $\begin{array}{l}\text { Total cholesterol, } \\
\text { mg/dL }\end{array}$ & $177 \pm 24.05$ & $176 \pm 9.13$ & $181 \pm 9.13$ & 0.164 & 0.850 \\
\hline HDL, mg/dL & $41 \pm 6.26$ & $44 \pm 2.39$ & $44 \pm 2.39$ & 0.183 & 0.830 \\
\hline $\begin{array}{l}\text { LDL, mg/dL } \\
\text { Triglycerides, mg/dL }\end{array}$ & $104 \pm 18.96$ & $100 \pm 7.24$ & $107 \pm 7.24$ & 0.505 & 0.600 \\
\hline Omentin, ng/mL & $561 \pm 509$ & $636 \pm 375$ & $567 \pm 344$ & 0.702 & 0.281 \\
\hline $\begin{array}{l}\text { Data are represented as mean } \pm S D \text {. Categorical variables are displayed as number of } \\
\text { patients. F and P values for One-way ANOVA or chi-square analysis } \\
\text { BMI - body mass index, CAD }- \text { coronary artery disease, HDL - high density lipoprotein, } \\
\text { LDL - low density lipoprotein,Val/Val=GTC/GTC. Val/Asp=GTC/GAC, Asp/Asp=GAC/GAC }\end{array}$ & $154 \pm 16.48$ & $167 \pm 16.48$ & 0.347 & 0.708 \\
\hline
\end{tabular}

with increasing obesity and insulin resistance. Furthermore, serum omentin-1 levels were shown to be inversely associated with the presence and severity of coronary artery disease in patients with metabolic syndrome (27). This data showed that there may be a putative role of human omentin gene missense variation in patients with cardiovascular disease. However, Schäffler et al. (14) could not show any significant association between genotype subgroups and anthropometric or laboratory parameters in patients with type $2 \mathrm{DM}$. We have further analyzed omentin gene polymorphism in CAD and could not show any significant difference. However, there was a 2.5 fold increase in $\mathrm{Val} / \mathrm{Val}$ homozygous mutant in patients with CAD indicating a larger study in different populations.

\section{Study limitations}

A possible limitation of the study was the small number of population. Further studies with larger study population are mandatory. In addition other polymorphisms in omentin gene also should be analyzed.

\section{Conclusion}

It can be concluded from our data that Val/Val genotype increases the tendency for CAD however there was no signifi- 
cant difference between CAD patients and control subjects regarding omentin Val109Asp polymorphism.

Acknowledgements: This project is supported by Düzce University Research Fund, Project Number 2011.04.HD.022.

Conflict of interest: None declared.

Peer-review: Externally peer-reviewed.

Authorship contributions: Concept - Ü.Y., K.O.Y., H.Ö.; Design - Ü.Y., K.O.Y., H.Ö.; Supervision - K.O.Y., H.Ö., S.B., R.M.; Resource - K.O.Y., H.Ö., R.M., A.K., S.B.; Materials - A.K., S.B., Y.A., C.B.; Data collection\&/or Processing - R.M., A.K., S.B., Y.A., C.B.; Analysis \&/or interpretation - K.O.Y., H.Ö., R.M., E.K.; Literature search - Ü.Y., K.O.Y., H.Ö., A.K., S.B., Y.A., C.B.; Writing - Ü.Y., K.O.Y., H.Ö.; Critical review - Ü.Y., K.O.Y., H.Ö., R.M., A.K., S.B., Y.A., C.B., E.K.; Other - H.Ö., R.M., E.K.

\section{References}

1. Go AS, Mozaffarian D, Roger VL, Benjamin EJ, Berry JD, Borden WB, et al. American Heart Association Statistics Committee and Stroke Statistics Subcommittee. Heart disease and stroke statistics-2013 update: a report from the American Heart Association. Circulation 2013; 127: e6-e245. [CrossRef]

2. Hansson GK. Inflammation, atherosclerosis, and coronary artery disease. N Engl J Med 2005; 352: 1685-95. [CrossRef]

3. Miyoshi T, Doi M, Hirohata S, Sakane K, Kamikawa S, Kitawaki T, et al. Cardio-ankle vascular index is independently associated with the severity of coronary atherosclerosis and left ventricular function in patients with ischemic heart disease. J Atheroscler Thromb 2010; 17: 249-58. [CrossRef]

4. Kajiya M, Miyoshi T, Doi M, Usui S, Iwamoto M, Takeda K, et al. Serum adipocyte fatty acid-binding protein is independently associated with complex coronary lesions in patients with stable coronary artery disease. Heart Vessels 2013; 28: 696-703. [CrossRef]

5. Yaykasli KO, Dogan M, Kaya E, Ozsahin M, Yaykasli E, Ataoglu S, Yuce $H$. The upregulation of matrix metalloproteinase-2 and -9 genes caused by resistin in human chondrocytes, Acta Medica Anatolia 2014; 2(1): 19-23. [CrossRef]

6. Fukuhara A, Matsuda M, Nishizawa M, Segawa K, Tanaka M, Kishimoto $K$, et al. Visfatin: a protein secreted by visceral fat that mimics the effects of insulin. Science 2005; 307: 426-30. [CrossRef]

7. Alçelik A, Tosun M, Özlü MF, Eroğlu M, Aktaş G, Kemahli E, et al. Serum levels of omentin in end-stage renal disease patients. Kidney Blood Press Res 2012; 35: 511-6. [CrossRef]

8. Yang $R Z$, Lee MJ, Hu $H$, Pray J, Wu HB, Hansen $B C$, et al. Identification of omentin as a novel depot-specific adipokine in human adipose tissue: possible role in modulating insulin action. Am J Physiol Endocrinol Metab 2006; 290: E1253-61. [CrossRef]
9. Kralisch S, Klein J, Bluher M, Paschke R, Stumvoll M, Fasshauer M, et al. Therapeutic perspectives of adipocytokines. Expert Opin Pharmacother 2005; 6: 863-72. [CrossRef]

10. Yang RZ, Shuldiner AR, Gong DW. Cloning of omentin, a new adipokine from human omental fat tissue. NCBI nucleotide database, 2003; Accession Number: AY549722.

11. Zhong X, Zhang HY, Tan H, Zhou Y, Liu FL, Chen FO, et al. Association of serum omentin-1 levels with coronary artery disease. Acta Pharmacol Sin 2011; 32: 873-8. [CrossRef]

12. Shibata R, Ouchi N, Kikuchi R, Takahashi R, Takeshita K, Kataovka $\mathrm{Y}$, et al. Circulating omentin is associated with coronary artery disease in men. Atherosclerosis 2011; 219: 811-4. [CrossRef]

13. Soydinç S, Çelik A, Ermiyürek S, Davutoğlu V, Tarakçıŏlu M, Aksoy $M$. The relationship between oxidative stress, nitric oxide, and coronary artery disease. Eur J Gen Med 2007; 4:62-6.

14. Turan H, Yaykaşlı KO, Soğuktaş H, Yaykaşlı E, Aliağaoğlu C, Erdem T, et al. Omentin serum levels and omentin gene Val109Asp polymorphism in patients with psoriasis. Int J Dermatol 2014; 53: 601-5. [CrossRef]

15. Yaykasli KO, Rheumatoid arthritis and adipokines. Eur J Basic Med Sci 2013; 3(2): 38-43.

16. Wozniak SE, Gee LL, Wachtel MS, Frezza EE. Adipose tissue: the new endocrine organ? A review article. Dig Dis Sci 2009; 54: 1847-56. [CrossRef]

17. Wang Z, Nakayama T. Inflammation, a link between obesity and cardiovascular disease. Mediators Inflamm 2010; 2010: 535918.

18. Sattar N, Wannamethee G, Sarwar N, Chernova J, Lawlor DA, Kelly $A$, et al. Leptin and coronary heart disease: prospective study and systematic review. J Am Coll Cardiol 2009; 53: 167-75. [CrossRef]

19. Ding 0 , White SP, Ling C, Zhou W. Resistin and cardiovascular disease. Trends Cardiovasc Med 2011; 21: 20-7. [CrossRef]

20. Shams M, Rasekhi Kazerouni A, Ostovan MA, Omrani GR. The relationship between serum adiponectin levels with the presence and severity of coronary artery disease. Arch Iran Med 2012; 15: 611-6.

21. Yan JJ, Tang NP, Tang JJ, Jia EZ, Wang MW, Wang OM, et al. Genetic variant in visfatin gene promoter is associated with decreased risk of coronary artery disease in a Chinese population. Clin Chim Acta 2010; 411: 26-30. [CrossRef]

22. Zhang $\mathrm{H}$, Cui J, Zhang C. Emerging role of adipokines as mediators in atherosclerosis. World J Cardiol 2010; 2: 370-6. [CrossRef]

23. Tan BK, Adya R, Randeva HS. Omentin: a novel link between inflammation, diabesity, and cardiovascular disease. Trends Cardiovasc Med 2010; 20: 143-8. [CrossRef]

24. Moreno-Navarrete JM, Ortega F, Castro A, Sabater M, Ricart W, Fernández-Real JM. Circulating omentin as a novel biomarker of endothelial dysfunction. Obesity 2011; 19: 1552-9. [CrossRef]

25. Liu R, Wang X, Bu P. Omentin-1 is associated with carotid atherosclerosis in patients with metabolic syndrome. Diabetes Res Clin Pract 2011; 93: 21-5. [CrossRef]

26. De Souza Batista CM, Yang RZ, Lee MJ, Glynn NM, Yu DZ, Pray J, et al. Omentin plasma levels and gene expression are decreased in obesity. Diabetes 2007; 56: 1655-61. [CrossRef]

27. Shang FJ, Wang JP, Liu XT, Zheng QS, Xue YS, Wang B, et al. Serum omentin-1 levels are inversely associated with the presence and severity of coronary artery disease in patients with metabolic syndrome. Biomarkers 2011; 16: 657-62. [CrossRef] 
Copyright of Anatolian Journal of Cardiology / Anadolu Kardiyoloji Dergisi is the property of Aves Yayincilik Ltd. STI and its content may not be copied or emailed to multiple sites or posted to a listserv without the copyright holder's express written permission. However, users may print, download, or email articles for individual use. 